\title{
4. Rule by Natural Reason: Late Medieval and early Renaissance conceptions of political corruption
}

\author{
Manuhuia Barcham
}

This paper argues that, from about the eleventh century $\mathrm{CE}$, a new and distinctive model of corruption accompanied the rediscovery and increased availability of a number of classical texts and ideals, particularly those of Cicero and the Roman Jurists. This new model of corruption accompanied a renewed emphasis on classical ideals in theorising the political, and a subsequent change in the way in which political life was conceived in Europe. Combining the medieval Christian focus on the importance of moral values with the classical emphasis on the value of reason, this tradition merged political and moral reason such that they became conceptually identical and indistinguishable from one another. The polity was thus seen as a Christian community living under laws agreed on through reason, ruled on behalf of the common good by a ruler who was bound and constrained by these same laws. In this new conceptual model, corruption was perceived largely in terms of the adverse consequences of action occurring without regard to natural reason, in contrast with the previous Augustinian approach that had viewed our entire earthly life as corrupt and without possibility of redemption.

\section{The Augustinian context}

Following the collapse of the Western Roman Empire in the fifth century, an Augustinian approach to the concept of the political as order provided the most influential framework within which political life was discussed and studied in Christian Europe. Augustine's work presented a political theory that placed earthly political institutions within the context of Christian theology. Probably his most radical departure from the classical tradition consisted in rethinking the role of politics and political institutions in human affairs. Augustine viewed earthly life in the wake of the Fall as inherently corrupt. He differed from earlier classical conceptions in viewing politics and political life as necessary evils requisite to achieve a semblance of order in earthly life. In Augustine's work, the idea of the 'good' life achievable on earth - so important to classical conceptions of the political or its corruption - was dropped from the vocabulary of European political discourse. For Augustine, politics was concerned merely with preserving external peace and order-not with shaping the moral 
character of the citizens. At best, all laws could do was secure civic order. It is this Augustinian background that provided the framework for much political thought in medieval Europe.

\section{Medieval Europe}

Medieval Europe consisted of an assortment of secular realms existing in accord with the Catholic Church under the wider rubric of the greater Christian commonwealth (res publica christiana). Europe was seen as a single Christian society governed by two powers with different but complementary roles: the regnum (secular government) dealt with temporal matters and the sacerdotium (ecclesiastical government) dealt with spiritual matters. Within this Christian commonwealth, both secular and ecclesiastical rulers were seen as deriving their power from God.

During this period, secular and ecclesiastical authorities were intricately intertwined; however, the church lacked a machinery of government and so the Pope had little jurisdictional or coercive power. Thus the Pope depended on the goodwill and piety of secular rulers to implement ecclesiastical policies. To facilitate this process, the church had become increasingly involved in secular government. Discontent from various quarters within the church with this increased involvement in secular affairs led, from the tenth century, to various popes initiating a number of programs of reform designed to refocus the church on matters of theology and away from the secular powerbrokering role that the church had increasingly held.

A consequence of this broad movement of reform over the tenth to twelfth centuries was an increase in the tensions and conflict between regnum and sacerdotium. As will become clear later in this chapter, religious interference in the political came to be seen as a form of corruption, based on the belief that these two spheres of human interaction should be distinct.

The conflict between regnum and sacerdotium came to a head in the late eleventh and early twelfth centuries, in the form of the investiture controversy. Conflict over lay investiture and the accompanying charges of simony (the act of buying or selling ecclesiastical benefices or emoluments) led Pope Gregory VII to declare sacerdotal and secular supremacy over all princely sovereignties. Simony was seen as a form of corruption, not because it represented the transfer of funds and favours in exchange for a particular outcome, but rather because it represented the encroachment of temporal affairs into the concerns of ecclesiastical government. King Henry IV of Germany considered that Pope Gregory VII's decree abridged his authority over the episcopacy and impinged on his rights as king. The resulting controversy came to an official end only in 
1122, when Henry V and Pope Calixtus II agreed at the Concordat of Worms that secular rulers would only invest bishops with the symbols of their temporal possessions and leave the ecclesiastical establishment to invest them with the symbols of ecclesiastical authority.

Despite apparent conclusion, this controversy had opened up a debate over the relationship between regnum and sacerdotium that was to continue on and off for the greater part of the next five centuries. The major issue in this debate concerned the extent of the church's jurisdictional authority. One of the early claims by papacy supporters was the Augustinian-derived assertion that the only way to redeem earthly government from being wholly sinful would be the complete submission of earthly princes to the papacy's guidance (Tierney, 1964, pp. 33-95). In arguing this, the papacy supporters used the two-swords doctrine to support their hierocratic claims that the church exercised ultimate authority over the governance of temporal affairs (Robinson, 1991). ${ }^{1}$

The continuing conflict between regnum and sacerdotium over these issues was to have important consequences for the way in which political life was approached and theorised. Underlying these developments was a particular approach to the concept of politics and political life, which had emerged out of the confluence of the extant classical - particularly Ciceronian-tradition and the strongly Augustinian-influenced Christian tradition.

\section{Political life and natural reason}

In the work of John of Salisbury we see a mixing of the Ciceronian republican tradition with Christian doctrine. In his writings, the Christian ruler was limited in the exercise of his power through the use of the Ciceronian notion of the utilitas publica (public good), which John used to elaborate the Christian ministerial idea of rulership. As a public power subject to the rule of law, the ruler was thus the minister of the common good and the servant of equity. ${ }^{2}$ If the king ruled in accord with the law, he was a just prince; however, if he broke the law, the ruler ceased to be a monarch, becoming instead merely a tyrant, with the rule of a tyrant seen as a corrupted form of monarchic rule (John of Salisbury, 1990

\footnotetext{
1 The two-swords doctrine concerned the division of earthly power between temporal and religious authorities. It was articulated first by Pope Gelasius I, who claimed that power was to be equally divided among these two aspects of the Christian world, but that true primacy lay with the church. This doctrine was to be the basis of dispute between temporal and religious rulers until the collapse of the Christian commonwealth in the wake of the Reformation and the Wars of Religion.

2 When talking about the nature of rule and discussing the character and roles of the ruler in the Policraticus, John of Salisbury uses the Latin term principes (leading statesman) rather than the term regis (king). This distinction is an important one for the purposes of this paper. In using this distinction, John of Salisbury signalled the continued existence of a distinction within European thought between rule for oneself and rule for the sake of the community.
} 
[c. 1159], VIII, 17). Thus, although unfamiliar with Aristotle's Politics, John of Salisbury developed a conception of rule easily identifiable with earlier classical conceptions of rule. John of Salisbury differed, however, from the classical texts when, following the received dogma of the time, he argued along hierocratic lines that temporal rulers received their authority through the church, because kingship was a gift conferred by divine grace (John of Salisbury, 1990 [c. 1159], VIII, 14). ${ }^{3}$ One of the key results of this claim was that John of Salisbury made no mention of the possibility of any other form of rule apart from monarchy, and his discussion of government focused almost entirely on the moral character and fortitude of the prince, making explicit the notion that only a good man could be a good ruler (John of Salisbury, 1990 [c. 1159], VI, 29).

This image of the political man - the ideal ruler - and the virtues he possessed was a key focus of works of political analysis from the eleventh to the thirteenth centuries. Writers during this period argued that governing should consist of restraining and moderating men so as to protect them from their own excesses, as only a man capable of submitting his own passions to reason could succeed in keeping a kingdom peaceful and united (Giles of Rome, 2001 [1277], I, 1.2). The political and the moral were therefore intricately connected, with the moral quality of rulers having direct impact on the quality of their rule 'because the lord is like the head of the citizens, and all men desire to have a healthy head, because when the head is sick, men must above all things try to have a governor who will lead to a good end according to law and justice' (Latini, 1939 [c. 1266], III, 75). Of all the virtues that leaders should have, prudence-that is, rule according to the dictates of natural reason - was the first and most important, although the virtue of justice was close behind prudence in terms of importance, because the good prince must also be the guardian of the laws (Latini, 1939 [c. 1266], II, 70-1). A man without the correct moral character would corrupt a city by bringing about division and conflict through the promotion of his own welfare rather than the common good. Such a leader would be a corrupted public figure - a tyrant.

Until the early thirteenth century, political analyses thus focused on the virtues and character of the ruler; however, the reintroduction of Aristotle's political and ethical works in the mid-thirteenth century shifted the focus of political inquiry away from the qualities of the ruler and towards an increased focus on the comparative merits of various regime types. Giles of Rome thus argued in his On the rule of princes that monarchy was superior to republican forms of self-government because political rule led to discord and war while monarchical rule resulted in concord and peace (2001 [1277], III, 2.3). The other major

3 For more on the hierocratic interpretation of the Pope as the source of both spiritual and temporal power, see Ullmann (1972, p. 223). 
consequence of the reintroduction of Aristotelian works was the recognition that, contrary to the received Augustinian view, politics was a natural form of human interaction that could be seen as a good in and of itself.

Yet this reintroduction of the classical idea that politics was a good in and of itself should not be seen as a simple refutation of the Augustinian notion of politics. In fact, the relationship between these two traditions of the political was rather complicated. The reintroduction of ideas from the older conceptual political schema did not necessarily lead to their wholesale adoption but, rather, to a novel form of synthesis where the older ideals were adapted to serve contemporary concerns and interests.

One important consequence of this reintroduced Aristotelian corpus was the space it created for the belief in the existence of a form of earthly good - a form of earthly beatitude - without removing the ideal of a final Christian beatitude. This belief had been explicitly denied to humanity in the Augustinian tradition. The idea of the two-ends of man would go on to play a vital role in the shaping of political thought within Europe in the next 400 years, with its influence felt nowhere more keenly than in the ongoing battle for dominance between regnum and sacerdotium. Among the many who began to explore the various implications of these ideas none was more famous, or more influential, than Thomas Aquinas.

\section{Earthly beatitude}

Following Aristotle, Aquinas argued that humanity's rational and social capacities were what led to political government, not human sin (Aquinas, 1964 [c. 1273], Ia.XCII: 1 ad 3, Ia.XCIV:4 resp). Politics was thus not an activity to be shunned but one that should be embraced as an important aspect of individual and collective moral growth and wellbeing (Aquinas, 1997 [c. 1265], 1.15.6).

In the late thirteenth century, Aquinas's Aristotelian-influenced writings were central to the renewal of the classical belief that humanity was endowed with certain earthly potentialities that could only be achieved within a human community. Civic life allowed humanity to live together in justice and virtue, thereby providing the medium by which humanity would be able to attain the moral excellence that was humanity's earthly end.

Aquinas argued that, in order to achieve this earthly end, men must practise their political virtues (Aquinas, 1964 [c. 1273], Ia-IIae.LI:2 resp). Natural law provided the framework within which the good life could be achieved, as law was 'an ordinance of reason for the common good made by the authority which has care of the community and promulgated' (Aquinas, 1964 [c. 1273], 
Ia.CIII:3 resp). The ruler was obliged to keep the common good in mind when he legislated, and corrupt governments were those that were directed towards the private good of the ruler rather than the common good of the community (Aquinas, 1964 [c. 1273], Ia-IIae.XC:2). For Aquinas, as for John of Salisbury before him, a ruler concerned with his own wellbeing rather than with the common good was nothing more than a tyrant. Unlike earlier medieval authors, however, Aquinas did not place exclusive emphasis on the necessary qualities required for a good ruler, although he did agree that the good ruler was also necessarily a good man.

One of the major consequences of the Aristotelian turn in the writings of Aquinas and the other scholastics was a renewed focus on constitutional form when considering the ends of government. Following Aristotle, Aquinas argued that political regimes dissolve and become corrupt when the citizenry is oppressed by a tyrant or when factions disrupt civic concord and fight over control for the city. Since the political community must above all else be peaceful and unified, the best form of government is that which most easily secures those ends. For Aquinas, this was monarchy, as government by a multitude was prone to disunity. Hence his claim that 'unity or peace is the aim intended by the ruler of any group...for this reason any group is better governed by one person than by many' (Aquinas, 1964 [c. 1273], Ia.CIII:3 resp). For Aquinas, the best order is achieved in a monarchy where the people actively participate in the election of the ruler. ${ }^{4}$

Aquinas's belief in the natural superiority of monarchy should not give the impression that all scholastic authors thought along the same lines. Ptolemy of Lucca argued instead for some form of popular rule (Ptolemy of Lucca, 1997 [c. 1300], 2.8 and 4.1); however, one thing Aquinas did agree on was that peace was best maintained within the community where all were involved in public affairs (Aquinas, 1997 [c. 1265], 1.2 and 1.5).

Good rulers, however, still needed to carry out their duties for love of God and not for personal glory. It is at this point that the key difference between the classical reading of the Aristotelian need for virtue and the medieval concern for Christian morality becomes apparent. A number of classical virtues were still seen as vices in the Christian tradition and so, despite the adoption of many classical ideals by medieval authors, they still perceived the pursuit of eudaimonia - so central a concept to classical political and ethical thought - as a form of sinful self-pride.

Thus, the need for the good ruler or person to cultivate the Christian virtues always existed in a form of tension with the Christian perception of self-love as

4 Aquinas calls this type of elected monarchy political rule as opposed to regal rule, which was typical of monarchical forms of government where the people do not participate in public life. 
a type of sin. Although Aquinas adopted many classical ideals, his writing was still conceived within the context of a living Christian tradition. The scholastic adoption of older classical ideals of the political was only ever at best partial and incomplete.

\section{Discord and conflict in the Christian commonwealth}

The emergence of scholastic thought in the thirteenth century coincided with the growth of the temporal power of the papacy. Polemical attacks continued as papacy and empire struggled over the nature of relationship between sacerdotium and regnum.

In the twelfth and thirteenth centuries, the key issue dividing papacy and empire was the Emperor's claim over Italy (Tierney, 1964, pp. 97-115). To the papacy it seemed that if an emperor claimed sovereignty over Rome, the inevitable next step would be the resumption of temporal control of the papacy-something the papacy was determined to prevent. This matter was complicated somewhat, because from about the tenth century a number of urban communes in northern Italy had begun to resist the claims of the German kings by establishing their own republican forms of government. These city-states were unprecedented at this time. Republican self-government was a form of political life completely at odds with the generally held assumption that all properly constituted political societies must take the form of hereditary God-given lordships. Conflict thus ensued between these states and the Holy Roman Emperor.

During the ongoing struggle with the Empire, the papacy had been the major ally of the city-states; however, the danger of this alliance for these republican cities was that the popes might begin to aspire to rule the northern Italian city-states themselves - and this is precisely what happened. From the early thirteenth century, successive popes began increasingly to dabble in the internal politics of the city-states. The result of this internal meddling was that, by the end of the thirteenth century, not only was a large part of central Italy under the direct control of the papacy but the curia also exercised a large degree of influence over many of the major northern city-states (Skinner, 1978, pp. 9-22). Rediscovered Aristotelian works provided the political vocabulary and conceptual apparatus through which these oppositional ideologies and legitimating claims were constructed. And, in constructing their arguments, the apologists for these new republics used a political concept that had not often been used before - that of liberty (Skinner, 1978, pp. 6-12). 
The situation was more complicated, however, for apologists for republican rule than having simply to legitimate their independence and continued liberty. The continuing struggle between papacy and empire, as well as the growth of the commercial classes in twelfth and thirteenth-century Europe, introduced a number of complicating factors. Issues of faction and civic discord came to be identified by many writers of this period as major threats to the continued existence of the republican city-states. Faction was viewed as being anathema to the realisation of the goal of liberty because faction was a form of domination by others - not too dissimilar from tyranny. Faction was especially corrupting of political life because of the discord and divisiveness that inevitably arose from its existence.

Often posing this problem in terms of the ongoing struggle between regnum and sacerdotium, a number of these authors argued that the papacy was the root cause of much of the internal discord and factionalism within the Italian city-states. Thus, Marsilius of Padua claimed that 'the singular cause which has hitherto produced civil discord or intranquility in certain states and communities...is the belief, desire and undertaking whereby the Roman bishop and his clerical coterie, in particular, are aiming to seize secular rulerships and to possess excessive temporal wealth' (Marsilius of Padua, 1956 [1324], 3.1). The corruption of the church about which Marsilius writes harks back to an older argument over the correct relationship between the regnum and the sacerdotium. In their writings, apologists for both sides had accused one another of corrupting the proper relationship between the two aspects of Christian government. Marsilius's arguments about the corrupt nature of the church can be seen as yet another example of this form of boundary-keeping, which saw the intrusion of the ecclesiastical into temporal affairs as a form of corruption.

Similarly, Dante Alighieri in his treatise on Monarchy argued for the independence of the empire from ecclesiastical rule. In arguing this, he drew on the same basic assumptions of the ongoing debate between regnum and sacerdotium that Marsilius of Padua and the other opponents of the temporal tyranny of the papacy had utilised. Dante placed particular emphasis on his argument that the two-swords doctrine had been wrongly interpreted (Alighieri, 1996 [c. 1313], 3.9). While these theorists were predominantly hostile to the papacy, they were nonetheless still concerned with the preservation of the Christian commonwealth and the idea of Christendom - even though the church should confine its concerns to the immortal souls of the community (Alighieri, 1996 [c. 1313], 3.16). To do otherwise was to corrupt the correct relationship between temporal and ecclesiastical government. 


\section{Popular rule and the rise of podestà}

As Quentin Skinner (1978) has argued, the most original aspect in the writings of these apologists for the Italian city-states was their assertion that popular rule was itself the best form of government (p. 61). The safest plan to ensure the preservation of peace, and thereby maintain concord within the community, would be to vest the power of government in the hands of the people (Bartolus of Sassoferrato, 1997 [c. 1330]a, 420; Marsilius of Padua, 1956 [1324], 1.12.3; Ptolemy of Lucca, 1997 [c. 1300], 4.23). If one hoped to forestall the development of factions or divided jurisdictions, the people must serve as the sole judicial, as well as the sole executive, authority within their polity (Marsilius of Padua, 1956 [1324], 1.12 and 1.17). If peace and the means to live the good life were to be preserved, the body of the people must thus remain sovereign at all times (Bartolus of Sassoferrato, 1997 [c. 1330]b, 16, 34).

While these various authors were writing to defend and legitimate the particular constitutional forms of the northern Italian city-states, a change was taking place within many of these republics. Continued strife and factionalism within the northern Italian city-states in the late thirteenth century eventually led many of them to elect individual leaders, known as podestà, in order to quell the discord and unrest that the continued conflict between factions within the cities was causing. The result of this continued conflict was that, by the early fourteenth century, almost all the city-states of northern Italy had moved away from their original popular forms of government towards princely rule. One consequence of this move was the emergence of a new body of literature designed to legitimate the emergence of these new princely governments.

Although this emergent body of literature celebrated the rise of podestà at the expense of the older forms of popular rule, it nonetheless maintained a familial resemblance to the earlier political tracts. The common good, achieved through a pacific harmony within the city, was still seen as the goal of government, and the writers of this new literature also agreed on the necessarily destructive consequences of civic discord within the body politic and that corruption would ensue if the ruler placed their own interests above those of the commonwealth (Petrarch, 1978 [c. 1350], pp. 46, 55). In fact, although the podestà was expected to rule for the common good and in the interests of peace, the continued discord and conflict of factionalism convinced many within these city-states that only rule by one could provide peace (Skinner, 1978, pp. 24-6).

These authors thus associated peace with good government, whereas discord was equated with tyranny and the loss of liberty (Marsilius of Padua, 1956 [1324], $1.3,1.5)$. Political rule, these authors argued, was prevented from descending into factionalism and conflict through the rule of virtuous rulers and the right 
ordering of the various parts of the polity: 'just as a building is stable when its parts are well laid down, so also a polity has firmness and perpetuity when all, whether rectors, officials, or subjects, work properly in their own ranks, as the action of their condition requires' (Ptolemy of Lucca, 1997 [c. 1300], 4.23).

Politics, then, was primarily the art of making good laws that were conducive to the achievement of the common good. Civic harmony and concord were necessary in achieving this end and so the unity of the citizens had to be the final aim of a ruler,

for if there is a single, corrupt humour which predominates in the whole body, that is bad; but if all the humours were corrupted, and were to struggle against each other, that would be the worst. Woe, therefore, to the city with many tyrants who did not aim at a single end. (Bartolus of Sassoferrato, 1997 [c. 1330]a, p. 36)

Despite their differences, both groups of authors still recognised a clear division between political and tyrannical rule. Political rule was rule according to right reason for the common good and not according to the passions of the ruler. In contrast, a tyrant was 'someone who acts tyrannically, that is, his acts tend not toward the common good but to the particular good of the tyrant. For this is ruling unlawfully' (Bartolus of Sassoferrato, 1997 [c. 1330]b, 59).

\section{The emergence of humanism}

In the fourteenth century, the debates between the apologists for the rule of the podestà and the supporters of popular rule took a new turn. Across Europe, but particularly within the Italian territories, a renewed focus was being placed on the study of the classical Roman authors - especially those from the late Republican period (Pfeiffer, 1976, pp. 3-16). Two key questions lay at the base of this new body of thought. What was the relationship between the general moral nature of the population of the city as a whole and good government? And how was the ruler of the city to be properly trained so as to possess the correct moral virtues for rule?

Humanists extended the notion of the virtuous leader to include the population of the polity as a whole. They began to argue that only when the population as a whole acted in a virtuous manner could the true ends of earthly government be achieved. The humanist authors therefore placed particular emphasis on the continued participation and interest of the general citizenry in the process of government. Not to act as a citizen was to promote the corruption of the republic and so was itself a form of corruption. In this nascent civic humanist tradition, then, as for all the earlier authors discussed in this chapter, corruption or 
tyranny (as it was sometimes described) arose when a private interest displaced or distorted the public interest and so disrupted the concordant nature of political life.

Despite this concern, the humanist literature of the fourteenth, fifteenth and sixteenth centuries argued that the general population neglected to cultivate virtue. So they must look to those who were more noble - those who possessed virtue - to rule them. In this view, the ends of earthly government depended on men of ability to lead the state (Morosini, 1992 [c. 1500], p. 70). An interesting example of the humanists' linkage between virtue and good rule is their treatment of the issue of avarice or greed. Combining the teachings of Roman Stoicism with Franciscan asceticism, humanist authors such as Petrarch and Salutati argued that external riches did not lead to virtue (Kohl, 1978, p. 231). Since avarice was a sin in the Christian moral tradition, the virtuous ruler ought to avoid excessive greed, as to do otherwise was to lead to political corruption (Petrarch, 1978 [c. 1350], p. 63).

The avoidance of morally repugnant practices such as avarice was of key importance in the development of the good prince, because the city's virtue depended upon its ruler's virtue. Combining the medieval Christian focus on the importance of moral values with the classical emphasis on the value of natural reason, the issue of avarice demonstrates the way in which political and moral reason were merged in Renaissance conceptions of the political, such that they became conceptually identical and indistinguishable from one another. The challenge of politics, then, was not to improve laws or institutions but to improve the moral quality of the ruler. The best way to achieve this was to train rulers in 'virtue and eloquence through the prolonged study of the ancient authors' (Petrarch, 1978 [c. 1350], p. 42).

\section{Honour, glory and liberty}

Like the earlier scholastic authors, these humanist authors believed that security and peace were among the main values of political life and so achieving them was the highest aim of government. They had different views, however, about how this aim might be achieved.

The scholastics argued that, in order to provide peace and security in his city, the good prince merely needed to possess the older political virtues combined with an inward devotion to God. The quest for honour and glory would inevitably lead to conflict and discord and so should be avoided at all costs. In contrast, the humanists argued, like the Romans before them, that glory was achieved 
through the pursuit of virtue and, since the achievement of virtue was at the basis of living the good life, the pursuit of glory was entirely compatible with the achievement of good government.

In reviving these older Roman ideals, these humanist authors also revived the older ideas of virtus and fortuna. ${ }^{5}$ This revival opened the way for an increased sense that human choice played a greater role in the events of the world than had previously been thought. The humanists thereby weakened the Christian idea of divine providence that had so firmly underpinned previous political thought and writing - though the humanists still wrote firmly within the Christian context of the final salvation and the goal of eternal beatitude.

In their writings, the humanist authors also strengthened the linkage between liberty, leading a virtuous life and good government, which had been developed by the supporters of popular rule in the northern Italian city-states during the twelfth and thirteenth centuries. According to the humanist authors, a person living his life according to reason was morally free and virtuous, since the rule of the passions over reason was a form of moral slavery. In a tyranny, the ruler, who was himself a slave to his passions, dominated free men like a master dominated bondsmen. In such a society, morality would degenerate and civic life would become corrupted. Of the various forms of government available, they argued, only that which produced maximum liberty would guarantee virtuous activity. Liberty for the humanist authors, as for earlier apologists for the Italian city-states, was the potential to live in freedom within the limits of both custom and law (Rinuccini, 1978 [c. 1479], pp. 193-222).

The greatness of a city was thus held to be a direct result of the liberty found within its walls. Florence, an example oft-quoted by these authors, was free from external conquest and free from faction, and so was able to speak with one voice - concordant and united. Like other humanist authors, Bruni (1978 [c. 1403]) felt that unity within a city was of the utmost importance. Unity was best promoted when the state alone was the font of honour. The creation of an ethic of public service, and hence love of the state, would be lacking if there were other sources of honour.

The notion of the primacy of the state reflected the collapse of feudalism and the disintegration of the conceptual union between regnum and sacerdotium that was occurring in the fourteenth and fifteenth centuries. This process led to the gradual transfer of political power away from these other estates and towards the emergence of an apparatus of government that existed independently from the person of the ruler - the beginnings of what we in the modern West would later know as the state (Skinner, 1978, 2002).

5 Augustine had refuted the existence of the twin goddesses of Virtus and Fortuna through the claim that there existed no conception of fate separate from God's providence. 


\section{The art of politics and the art of the state}

Machiavelli and Guicciardini both agreed with earlier humanist writers that the pursuit of the common good - and not the pursuit of private interests - was the cause of greatness in cities (Guicciardini, 1994 [1527], p. 87; Machiavelli, 1989 [1525], 1, 2.2). For Machiavelli, to be a corrupt citizen was to place one's own ambitions, or the ends of faction, above the common good, because to act in this way was invariably fatal to liberty and hence greatness (Machiavelli, 1989 [1525], 1, 2.2; Skinner, 1990, p. 138). As for earlier authors, for these, a corrupt city was one where laws were disobeyed and people lived only to further their own self-interest.

The maintenance of a virtuous and free population was, for Machiavelli, as for earlier humanist authors, the key to good government because it was believed that it was both impossible for a tyranny to be established when the city was virtuous and impossible for a corrupted people to establish a virtuous government. Machiavelli wrote 'that where the matter [the population] is not corrupt, uprisings and other disturbances do no harm. Where it is corrupt, wellplanned laws are of no use, unless indeed they are prepared by one who with the utmost power can force their observation, so that the matter will become good' (Machiavelli, 1989 [1525], 1, 1.7). Nonetheless, he believed that this good government did not always come merely through the existence of good laws or just rule. It sometimes required employing force. He saw more clearly than other writers of his time the implications of Cicero's belief that the survival and advancement of a republic should take precedence over all things, even at the expense of conventional virtuous and moral behaviour (Tuck, 1993, p. 20). The problem, as Machiavelli puts it, is that a good man must become bad in order to achieve the goal that the good man ought to pursue (Viroli, 1992, p. 175). In a corrupt city, despotic power is the only way out of corruption and so government becomes a quest for security (Machiavelli, 1989 [1525], p. 66).

Machiavelli's contemporary, Guicciardini, was even more pessimistic in his assessment of the hopes for reform of a corrupt city. Like Machiavelli, he argued that persuasion on its own would not work because people within a corrupt city are too accustomed to the type of corrupted life they lead. Nonetheless, he also thought that trying to find a good man to rescue the constitution by force was a risky proposition. For Guicciardini, to ensure that the city did not sink again into corruption, the 'good' man would need to stay in power for a considerable time - and would probably become accustomed to that power and so not want to step aside - thus becoming merely a tyrant, itself a corruption of good government (Guicciardini, 1994 [1527], p. 139). 
In light of this problem, Guicciardini argued that ruling or reforming a city required the same competence that citizens acquired through the practice of commerce and the administration of their estates. He went further than his contemporary Machiavelli in addressing the way in which rulers in the sixteenth century could maintain their position through bribery and manipulation. In doing so, he weakened the previously necessary connection between the private morality of the prince and the quality of his rule. ${ }^{6}$ Guicciardini argued far more explicitly than Machiavelli that politics - by which he meant restraining private loyalties and reinforcing impersonal attachments such as love for liberty, justice and one's country - was sometimes not enough to ensure the survival of the city. So the ruler of a republic must sometimes, in extreme circumstances, resort to the 'art of the state' - the art of consolidating and creating private loyalties in order to ensure the survival of the city.

In saying that there was a reason of state that transcended moral reason, Guicciardini should thus be understood as arguing that the language of politics was only appropriate within certain bounds: a republic understood as a community of citizens. Guicciardini makes the innovative and truly revolutionary leap that in extreme circumstances governmental reason may actually justify cruelties and injustices. This intellectual leap can be understood better through reference to Mark Phillips' argument that, whereas Machiavelli was motivated in his writings by a concern for liberty, Guicciardini was more concerned with the achievement of order (Phillips, 1977, p. 85).

In the writings of Machiavelli and Guicciardini, then, we see a number of important changes in the way in which the conduct and process of government were theorised in relation to conceptions of corruption. In their writings, the traditionally necessary connection between the individual morality of the ruler and the quality of his rule was uncoupled for the first time. This uncoupling led, in turn, to the emergence of a novel notion of political morality, whereby political morality began to be seen as separate and not necessarily connected to individual morality. Political prudence and virtue were thus no longer necessarily connected aspects of civic life; however, this disconnection was something that happened only in an extreme state of affairs. Political or civil life, for both Machiavelli and Guicciardini, was still seen as the opposite of tyranny and corruption (Machiavelli, 1989 [1525], 1, 1.25, 1.55, 3.8).

6 Machiavelli also argues along these lines that it is safer at times for a ruler to be feared than be loved. 


\section{The northern Renaissance and the Reformation}

While Machiavelli and Guicciardini pushed the traditional notion of government to its limit, the majority of thinkers across Europe in the fifteenth and sixteenth centuries continued to write within the broad context of the humanist tradition. The private morality of the ruler and the quality of his rule were thus seen as being necessarily connected (Erasmus, 1997 [1516], p. 21); however, as humanist writers of the northern Renaissance were composing these last and greatest humanistic treatises on good government, an additional intellectual revolution begun by Machiavelli and Guicciardini was gathering force. This intellectual revolution was set to reshape the political make-up of Europe and irrevocably alter the way in which the political itself in Europe was theorised.

With the publication of his 95 theses in 1517, the young Martin Luther set in train a course of events that was to rock Europe to its very core. Dissatisfied with what he saw as the irredeemable corruption of the Catholic Church brought about by its involvement in temporal affairs, Martin Luther and others, such as Jean Calvin who followed in his wake, used their writings to repudiate the temporal jurisdiction of the church. Arguing that the church was nothing more than the community of the faithful rather than the institutional structure that had claimed this role, Luther liberated Christians from the church's claims to mediate the relationship between God and the individual. In so doing, Luther effectively denied the church any jurisdictional power over temporal affairs.

These early Reformation writings had three major consequences for the model of political life discussed in this chapter. First, the return to a conception of politics as order - and thereby divorced from all ethical and moral contenthelped provide theoretical support for the separation of politics and morality that writers such as Machiavelli and Guicciardini had began to explore. Second, the repudiation of any need for a specific institutional structure for the church that these writers espoused meant that the traditional separation of the Christian commonwealth into regnum and sacerdotium had collapsed, leading in effect to the collapse of the very concept of a Christian commonwealth. And finally, the wars of religion that resulted from questioning the Catholic Church in Luther's writings introduced a period of violence, conflict and instability unlike anything Europe had seen before. In the late sixteenth and early seventeenth centuries, these three factors led many across Europe to the study of the art of the state. 


\section{Raison d'état triumphant}

Within this context of sectarian conflict and religious war, the writings of Justus Lipsius, Michel de Montaigne, Jean Bodin and others in the late sixteenth century augured an entirely new conception of politics. This new conceptual framework finally severed the Thomistic unity of public and private morality that was first put to the test in the writings of Machiavelli and Guicciardini. The new discourse of politics no longer described the conflict between moral reason and the interests of the state as a divergence between reason and the practice of statecraft. Instead, it was a conflict between moral reason and reason of state. For these authors, the maintenance of justice no longer always took precedence over the preservation of the polity itself (de Montaigne, 1946, p. 388).

In this new conception of politics and political life, governmental prudence was no longer seen as right reason acting in accord with justice. Instead, it was merely the capacity to decide what was most appropriate for the preservation of the state. People began to speak of the political prudence of tyrants - something previously unthinkable. The uncoupling of moral reason and political reason was the final death knell for the model of politics discussed in this chapter. With its uncoupling, the distinction between tyrant and monarch - of key importance to this understanding of political life - collapsed. Without this distinction, the model of corruption that had flowed from this understanding collapsed as well.

\section{Conclusion}

A distinctive model of political corruption, and thus politics, emerged in Europe from the early eleventh century. In this model, the medieval Christian focus on the importance of moral values was combined with the classical emphasis on the value of reason. This synthesis gave rise to the belief that natural reason provided the principles by which human life ought to proceed. By extension, a life not led in accord with these principles was seen as being necessarily corrupt.

The clearest example was the notion of prudence. For the authors who wrote within this tradition, prudence meant ruling according to the dictates of natural reason. Appeal to natural reason led these authors to intuit that only a good man could be a good king, since the necessarily all-encompassing nature of natural reason meant that political and moral reason must be identical. A ruler who lacked the requisite moral fortitude was a corrupt ruler - a tyrant - who could not be trusted to rule in terms of the common good.

Political corruption in this notion of politics was, therefore, intricately connected to natural reason. Actions that went against the principles of 
natural reason - principles that every right-regarding person would be able to intuit-were necessarily corrupt. This model of political life was initially relatively stable, because the Christian and classical traditions were seen as relatively complementary; however, towards the end of the Renaissance, the increasing influence of a number of late Roman Republican authors and their focus on issues of honour and glory began to place this model under strain. The subsequent separation of church and state in the wake of the Reformation, and the concomitant separation of moral reason from political reason in the writings of the raison d'état authors, eventually led to the complete collapse of these understandings of political life and the associated notion of political corruption. The belief that these aspects of human life possessed their own intrinsic rationality effectively denied the possibility for any appeal to the dictates of natural reason, and so the model of corruption that flowed from this understanding also collapsed.

\section{References}

Alighieri, Dante. (1996 [c. 1313]). Monarchy (Prue Shaw, Trans.). Cambridge: Cambridge University Press.

Aquinas, Thomas. (1964 [c. 1273]). Summa theologia. London: Blackfriars with Eyre \& Spottiswoode.

Aquinas, Thomas. (1997 [c. 1265]). On the government of rulers (James M. Blythe, Trans.). Ptolemy of Lucca. On the government of rulers: de regimine principum. Philadelphia: University of Pennsylvania Press.

Bartolus of Sassoferrato. (1997 [c. 1330]a). Treatise on the government of a city. Oxford: Oxford University History Faculty.

Bartolus of Sassoferrato. (1997 [c. 1330]b). Treatise on the tyrant. Oxford: Oxford University Press.

Bruni, Leonardo. (1978 [c. 1403]). Panegyric to the city of Florence. In Benjamin G. Kohl, Ronald G. Witt \& Elizabeth B. Welles (Eds), The earthly republic: Italian humanists on government and society (pp. 135-78). Manchester: Manchester University Press.

de Montaigne, Michel. (1946). The essays of Montaigne. New York: Random House.

Erasmus, Desiderius. (1997 [1516]). The education of a Christian prince with the panegyric for Archduke Philip of Austria (Neil M. Chesire \& Michael J. Heath, Trans). Cambridge: Cambridge University Press. 
Giles of Rome. (2001 [1277]). On the rule of princes (selected). In A. McGrade, John Kilcullen \& Matthew Kempshall (Eds), The Cambridge translations of medieval philosophical texts: ethics and political philosophy (pp. 200-15). Cambridge: Cambridge University Press.

Guicciardini, Francesco. (1994 [1527]). Dialogue on the government of Florence (Alison Brown, Trans.). Cambridge: Cambridge University Press.

John of Salisbury. (1990 [c. 1159]). Policraticus (Cary J. Nederman, Trans.). Cambridge: Cambridge University Press.

Kohl, B. G. (1978). Poggio Bracciolini: introduction. In B. G. Kohl \& Ronald G. Witt (Eds), The earthly republic: Italian humanists on government and society. Manchester: Manchester University Press.

Latini, Brunetto. (1939 [c. 1266]). The book of the treasure (Li Livres dou Trésor). New York: Garland Publishing.

Machiavelli, Niccolò. (1989 [1525]). Discourses on the first decade of Titus Livius. In A. Gilbert (Ed.), Machiavelli: the chief works and others. Durham: Duke University Press.

Marsilius of Padua. (1956 [1324]). The defender of the peace. New York: Harper \& Row.

Morosini, Domenico. (1992 [c. 1500]). Radical proposals by an aged patrician. In D. Chambers, Brian Pullan \& Jennifer Fletcher (Eds), Venice: a documentary history 1450-1630. Oxford: Blackwell.

Petrarch, Francesco. (1978 [c. 1350]). How a ruler ought to govern his state. In Benjamin G. Kohl \& Ronald G. Witt (Eds), The earthly republic: Italian humanists on government and society (pp. 35-81). Philadelphia: University of Pennsylvania Press.

Pfeiffer, Rudolph. (1976). History of classical scholarship from 1300 to 1850. Oxford: Oxford University Press.

Phillips, Mark. (1977). Francesco Guicciardini: the historian's craft. Manchester: Manchester University Press.

Ptolemy of Lucca. (1997 [c. 1300]). On the government of rulers. Philadelphia: University of Pennsylvania Press.

Rinuccini, Alamanno. (1978 [c. 1479]). Liberty. In Renee Neu Watkins (Ed.), Humanism and liberty: writings on freedom from fifteenth century Florence. Columbia: University of South Carolina Press. 
4. Rule by Natural Reason: Late Medieval and early Renaissance conceptions of political corruption

Robinson, Ian Stuart. (1991). Church and papacy. In J. H. Burns (Ed.), The Cambridge history of medieval political thought c. 350 - c. 1450 (pp. 252-305). Cambridge: Cambridge University Press.

Skinner, Quentin. (1978). The foundations of modern political thought. Cambridge: Cambridge University Press.

Skinner, Quentin. (1990). Machiavelli's discorsi and the pre-humanist origins of republican ideas. In G. Bock, Quentin Skinner \& Maurizio Viroli (Eds), Machiavelli and republicanism. Cambridge: Cambridge University Press.

Skinner, Quentin. (2002). From the state of princes to the person of the state. In Quentin Skinner (Ed.), Visions of politics: Renaissance virtues (Vol. 2). Cambridge: Cambridge University Press.

Tierney, Brian. (1964). The crisis of church and state 1050-1300. Englewood Cliffs: Prentice-Hall.

Tuck, Richard. (1993). Philosophy and government 1572-1651. Cambridge: Cambridge University Press.

Ullmann, Walter. (1972). A short history of the papacy in the Middle Ages. London: Methuen.

Viroli, Maurizio. (1992). From politics to reason of state: the acquisition and transformation of the language of politics 1250-1600. Cambridge: Cambridge University Press. 